\title{
Giovanna Angeli, Le masque de Lancelot. Lumières de la Renaissance au $X V^{\mathrm{e}}$ siècle
}

\section{Maria Colombo Timelli}

\section{(2) OpenEdition}

1 Journals

\section{Édition électronique}

URL : http://journals.openedition.org/studifrancesi/32808

DOI : 10.4000/studifrancesi.32808

ISSN : 2421-5856

Éditeur

Rosenberg \& Sellier

\section{Édition imprimée}

Date de publication : 1 décembre 2005

Pagination : 614

ISSN : 0039-2944

\section{Référence électronique}

Maria Colombo Timelli, « Giovanna Angeli, Le masque de Lancelot. Lumières de la Renaissance au XVe siècle », Studi Francesi [En ligne], 147 (XLX | III) | 2005, mis en ligne le 30 novembre 2015, consulté le 19 avril 2021. URL : http://journals.openedition.org/studifrancesi/32808 ; DOI : https://doi.org/10.4000/ studifrancesi.32808

Ce document a été généré automatiquement le 19 avril 2021.

\section{(c)}

Studi Francesi è distribuita con Licenza Creative Commons Attribuzione - Non commerciale - Non opere derivate 4.0 Internazionale. 
Giovanna Angeli, Le masque de Lancelot. Lumières de la Renaissance au $X V^{\mathrm{e}}$ siècle

Maria Colombo Timelli 


\section{RÉFÉRENCE}

GIOVANNA ANGELI, Le masque de Lancelot. Lumières de la Renaissance au XV siècle, Paris, Honoré Champion, 2004 («Etudes et essais sur la Remaissance», LII), 253 pp.

1 Traduction française du volume paru en italien en 1989 sous le titre La maschera di Lancillotto. Studi sul Quattrocento letterario francese (Roma, Salerno ed.; cf. «Studi francesi», CIV, 1991, p. 337). Par ailleurs, la modification du sous-titre et la parution dans une collection centrée plutôt sur le $\mathrm{XVI}^{\mathrm{e}}$ me paraissent indicatives des oscillations de la critique à l'égard de la production littéraire de la seconde moitié du XV $\mathrm{XV}^{\mathrm{e}}$ siècle. Si, il y a quinze ans, on aurait plutot opposé les premières «lumières» de la Renaissance au «déclin» ou à l'«automne» du Moyen Age vu par Huizinga, une nouvelle perspective paraît aujourd'hui acquise, et la littérature des dernières décennies du XV siècle n'a plus vraiment à défendre sa dignité. Les articles réunis dans ce volume portent sur trois gros sujets: Le texte narratif (Première partie: Les 'Cent Nouvelles nouvelles' contre le 'Décaméron', pp. 13-47; La transformation narrative du débat: les 'Quinze joyes de mariage' et 'Jehan de Saintré, pp. 48-65); La «Grande Rhétorique» (Deuxième partie: Le «rude engin» de Molinet, pp. 69-99; Le type-cadre du songe dans la production des «Grands Rhétoriqueurs», pp. 100-114; Le vieux et le nouveau monde d'André de la Vigne, pp. 115-141); Le théâtre (Troisième partie: «Mundus inversus» et «perversus». De la fatrasie à la sottie, pp. 145-165; Un exemple de bilinguisme dans le théâtre français du XV siècle, pp. 166-203; Persuasion absurde et manque d'identité dans le théâtre comique de la fin du moyen âge, pp. 204-220). La bibliographie, dans les notes ainsi que dans la section finale (pp. 221-241), a été partiellement mise à jour. Index aux pp. 243-251. 